\title{
MISI GEREJA MELALUI DUNIA POLITIK
}

\author{
Yohanis Udju Rohi
}

\section{PENDAHULUAN}

Mengamati situasi politik yang ada tentulah orang percaya atau Gereja harus mengambil sikap bekenaan dengan politik. Biasanya sikap orang percaya atau Gereja sebagai warga negara terhadap politik ialah bisa negatif atau positif. Memilih kedua sikap tersebut tentulah dilatarbelakangi oleh banyak faktor. Menurut Rungkat, orang percaya/Gereja terhadap politik bersikap antipati, curiga, pasif, dan manipulatif. Jadi ada Gereja yang melihat politik itu sebagai "momok" yang menakutkan dan "kotoran" yang menjijikkan. Karena itu mereka menentang semua peran Gereja dalam bidang politik.

Penyebab dari sikap negatif tersebut adalah: Pertama, kurangnya pengajaran, tidak seimbangnya pemberitaan dalam Gereja. Kedua, kenyataan perilaku politik yang kotor, tambah dengan pendapat-pendapat yang sumbang bahwa politik itu kotor, maka mereka menjadi pasif dan apatis terhadap politik dan akhirnya bersikap masa bodoh. Sikap negatif yang berikut adalah, ada juga yang seolah-olah melaksanakan misi Allah dalam dunia politik, tetapi "membabi-buta" tanpa persiapan, pegangan dan arah, akibatnya jatuh juga pada praktek politik praktis-manipulasi, menjadikan politik hanya menjadi mata pencaharian, bahkan sampai merampok rakyat dengan senjata politik. ${ }^{1}$

Karena itu sangatlah penting bagi Gereja untuk memberikan pemahaman terhadap warga Gereja yang adalah warga negara tentang arti penting politik dalam negara demi tercapainya kesejahtaan rakyat (syalom) dan bagaimana orang percaya atau Gereja bertindak dalam misi lewat ranah politik. Gereja adalah umat Allah yang dipanggil keluar dari kegelapan dan menjadi milik Allah dan telah mengalami pemulihan Allah. Gereja diberikan tugas yang mulia oleh Allah untuk menjadi alat pemulihan, sebagai garam dan terang dunia (Mat. 5:13-16). Fungsi Gereja sebagai garam dan terang harus dirasakan dan dialami oleh masyarakat, bangsa dan negara. \footnotetext{
2010), v-vi

${ }^{1}$ Jimmy Rungkat, Theologia Politik Yesus, (Batu: Departemen Literatur YPPII,
} 
Gereja harus dapat bermisi di tengah bangsa dan negara melalui berbagai bidang kehidupan bangsa, termasuk bidang politik. Misi Gereja secara organisasi tentulah bukan berpolitik praktis, tetapi menghadirkan ide dan pemikiran, memberitakan berita syalom bagi pembangunan manusia Indonesia seutuhnya (jasmani dan rohani).

\section{MISI GEREJA MELALUI DUNIA POLITIK}

\section{Pengertian Misi, Gereja dan Politik}

\section{Pengertian Misi}

\section{Menurut George W. Peters}

a) Misi adalah merujuk pada penugasan Gereja Yesus Kristus yang bersifat biblikal sepenuhnya. Penugasan tersebut adalah dalam suatu pengertian yang bersifat menyeluruh, termasuk pelayanan-pelayanan Gereja yang ke atas, ke dalam dan ke luar (termasuk dunia politik). Itulah Gereja yang seutuhnya ke dalam dunia.

b) Misi adalah pengutusan pribadi-pribadi yang berwibawa melampaui batas-batas Gereja Perjanjian Baru dan pengaruh Injil yang dibawanya untuk memberitakan Injil Yesus Kristus di wilayah-wilayah yang sangat miskin dan papa (wilayah korban politik), untuk memenangkan petobatpetobat dari iman mereka yang lain, tanpa iman dan beriman kepada Yesus Kristus, dan memberdayakan dan melipatgandakan Gereja-Gereja lokal yang akan menghasilkan buah kekristenan dalam masyarakat dan negara tersebut. ${ }^{2}$

\section{Menurut Donald Mcgarvan}

Membawa Injil melintasi batasan-batasan budaya, kepada mereka yang tidak ada hubungan dengan Yesus Kristus, dan mendorong mereka untuk menerima Dia sebagai Tuhan dan Juruselamat, dan menjadi anggota Gereja-Nya yang bertanggung jawab, bekerja, dalam pimpinan Roh Kudus, baik dalam bentuk penginjilan maupun dalam upaya keadilan, mewujudkan kehendak Allah di dunia seperti di Sorga (termasuk keadilan dalam ranah politik). ${ }^{3}$ 1974), 11

${ }^{2}$ George W. Peters, A Biblical Theology of Missions, (Chicago: Moody Press,

${ }^{3}$ Arthur F. Glasser, Donald A. McGavran, Contemporary Theologies of Mission, (Grand Rapids: Baker Book House, 1983), 26 


\section{Menurut Van Engen}

a) Umat Allah dengan internasional melintasi batasan-batasan dari wilayah Gereja kepada wilayah-wilayah tanpa Gereja, dari komunitas beriman kepada komunitas tidak beriman untuk memproklamasikan kedatangan Kerajaan Allah dalam Yesus Kristus melalui perkataan dan perbuatan (termasuk dunia politik).

b) Tugas tersebut terpenuhi melalui partisipasi Gereja dalam misi Allah, yang memulihkan manusia dengan Allah, dengan diri-Nya sendiri, dengan sesamanya (satu kepada yang lain), dan dengan dunia, dan mengumpulkan mereka ke dalam Gereja melalui pertobatan dan iman kepada Yesus Kristus oleh pekerjaan Roh Kudus, dengan maksud untuk transformasi dunia sebagai tanda kedatangan Kerajaan Allah dalam Yesus Kristus (termasuk dunia politik). ${ }^{4}$

\section{Menurut David J. Bosch}

a) Misi lebih luas dari penginjilan.

b) Evangelisasi adalah misi, misi tidak sekedar evangelisasi.

c) Karenanya penginjilan tidak boleh disamakan dengan misi.

d) Penginjilan dapat dipandang sebagai dimensi yang hakiki dari seluruh kegiatan Gereja.

e) Penginjilan melibatkan kesaksian tentang apa yang telah Allah, sedang dan akan perbuat.

f) Kendatipun demikian penginjilan toh membutuhkan satu tanggapan. Bertobatlah dan percayalah kepada Injil.

g) Penginjilan selalu berarti undangan

h) Orang yang menginjili adalah saksi, bukan hakim.

i) Meskipun kita harus bersikap rendah hati mengenai sifat dan efektivitas kesaksian kita, penginjilan tetap merupakan suatu pelayanan yang tidak dapat disisihkan.

j) Penginjilan hanyalah mungkin apabila komunitas yang menginjili itu Gereja menjadi perwujudan yang bercahaya dari iman Kristen dan memperlihatkan gaya hidup yang menarik.

k) Penginjilan menawarkan kepada manusia keselamatan sebagai karunia masa kini dan dengan jaminan sukacita yang kekal.

1) Penginjilan bukanlah proselitisme.

m) Penginjilan tidaklah sama dengan perluasan Gereja.

${ }^{4}$ Charles Van Engen, Mission on the Way: Issues in Mission Theology, (Grand Rapids: Baker Books, 1996), 26-27 
n) Meskipun demikian, membedakan penginjilan dengan rekrutmen anggota tidaklah berarti bahwa keduanya saling tidak terkait.

o) Dalam penginjilan hanya manusia yang dapat disapa dan hanya manusia yang dapat menjawab.

p) Penginjilan yang otentik selalu bersifat kontekstual (termasuk koteks dunia politik).

q) Karenanya, penginjilan tidak dapat dipisahkan dari pemberitaan dan praktek keadilan (termasuk keadilan dalam dunia politik).

r) Penginjilan bukanlah sebuah mekanisme untuk mempercepat kedatangan Kristus kembali, seperti yang dikatakan sebagian orang.

s) Penginjilan bukanlah hanya pemberitaan verbal.

t) Kendatipun demikian, penginjilan mempunyai dimensi verbal yang tidak dapat dielakkan. ${ }^{5}$

\section{Menurut J. R. W. Stott}

a) Misi bukanlah satu kata untuk segala sesuatu yang Gereja kerjakan. Gereja adalah mission 'sounds fine, tetapi itu bukanlah suatu pernyataan yang berlebih-lebihan. Karena Gereja adalah suatu komunitas yang menyembah dan melayani, dan sekalipun keduanya, baik menyembah maupun melayani adalah saling memiliki (tidak bisa dipisahkan satu sama lain), keduanya tidak menjadi kacau. Misi juga bukan dalam pengertian sebagaimana yang tertulis, bahwa misi adalah Allah mengatasi segala sesuatu dalam dunia. Karena Allah, Pencipta adalah aktif dan tetap memelihara dunia dalam anugerah-Nya, dan dalam penghakiman-Nya yang umum, terlepas dari maksud-maksud yang olehnya Ia mengutus Anak-Nya, Roh-Nya dan Gereja-Nya ke dalam dunia.

b) Misi menggambarkan lebih dari segala sesuatu yang dilakukan oleh Gereja, yang olehnya ia diutus ke dalam dunia. Misi mencakup wilayah kerja yang rangkap, yakni menjadi "garam dunia" dan "terang dunia". Karena Kristus mengutus umat-Nya ke dalam dunia untuk menjadi garam-Nya dan terang-Nya (Mat. 5:13-16) (termasuk bidang politik). ${ }^{6}$

Berdasarkan pengertian dan pendefinisian tentang misi, maka sesungguhnya misi Allah melalui Gereja haruslah holistik, termasuk dalam ranah politik, walaupun tentunya Gereja tidak boleh berpolitik secara praktis. Misi holistik biasa juga disebut pelayanan integral, yaitu pelayanan yang memperhatikan kebutuhan manusia seutuhnya: jiwa dan raga. Karena

5 David J. Bosch, Transformasi Misi Kristen: Sejarah Teologi Misi yang Mengubah dan Berubah, (Jakarta: BPK Gunung Mulia, 2000), 631-644

${ }^{6}$ John R. W. Stott, Christian Mission in the Modern Word, (London: Intervarsity Press, 1975), 30-31 
itu selain pelayanan penginjilan dan pelayanan rohani, dilakukan juga pelayanan sosial, pendidikan, makanan, medis, ekologi, dan sebagainya termasuk bidang politik, karena Tuhan Yesus mengasihi manusia seutuhnya dalam semua aspek dan bagian hidup. ${ }^{7}$

Selanjutnya Schunemann dan Huwae juga menuliskan bahwa misi mencakup pelayanan secara menyeluruh (holistik):

Yang dimaksud di sini adalah bahwa kebutuhan manusia secara menyeluruh baik rohani maupun jasmani dalam berbagai situasi kehidupan harus mendapat perhatian dalam pelaksanaan misi. Misi Sang Mesias yaitu Yesus sendiri bercirikan misi yang holistik (band. Yes. 61 dan Luk. 4). Hal ini mencakup pentingnya berita dan keputusan pertobatan dan pemulihan hubungan manusia dengan Allah, dengan sesama dan dengan dirinya sendiri serta pengembangan kehidupan spiritualitas, perjuangan untuk hak-hak azasi mausia, pemeliharaan lingkungan hidup serta bertanggung jawab, pendidikan, kesehatan, kesejahteraan sosial, kerukunan kehidupan masyarakat dan berbagai dimensi pelayanan lainnya yang perlu sesuai dengan situasi dan kondisi lokal maupun secara universal. ${ }^{8}$

\section{Pengertian Gereja}

Gereja adalah umat Allah. Dalam Perjanjian Lama, yaitu Ulangan 7:6 dituliskan bahwa Israel umat yang kudus bagi TUHAN, Allahnya, yang telah dipilih dari segala bangsa di atas muka bumi ini untuk menjadi umat kesayangan Tuhan. Umat yang kudus ini di dalam Perjanjian Lama disebut jemaat TUHAN (kahal Yahweh, yang dalam bahasa Yunani diterjemahan dengan ekklesia). ${ }^{9}$

Makna rohani dari kata ekklesia ialah sekelompok orang yang telah dipanggil keluar dari dunia dan dari hal-hal yang berdosa. Kata Gereja dalam bahasa Inggrisnya Church. Istilah Church dalam bahasa Inggris sebenarnya berasal dari bahasa Yunani kuriakos yang artinya: menjadi milik Allah. Dengan demikian, Gereja dapat disebut sekelompok orang yang telah dipanggil keluar dari dunia dan yang menjadi milik Allah. ${ }^{10}$

\footnotetext{
${ }^{7}$ John Ruck dkk, Jemaat Misioner, (Jakarta: Yayasan Komunikasi Bina Kasih, 2011), 18

${ }^{8}$ Rainer Scheunemann dan Carolis Huwae, Misi \& Penginjilan, (Papua: Sekolah Alkitab Malam Gereja Kristen Injili di Tanah Papua 2006), 13

${ }^{9}$ Harun Hadiwijono, Iman Kristen, (Jakarta: BPK Gunung Mulia, 2001), 363

${ }^{10}$ Henry C. Thiessen, Teologi Sistematika, (Malang: Gandum Mas, 2000), 476-477
} 
Berkenaan dengan misi, umat Allah dalam Perjanjian Lama (Isreal) dipilih oleh Allah menjadi umat kepunyaan/milik Allah dengan tujuan misi. Keberadaan bangsa Israel ialah untuk membawa keselamatan kepada bangsa-bangsa. Pemilihan Israel memiliki tujuan positif yaitu keselamatan. Keberadaan Israel dilihat sebagai suatu bagian dari keseluruhan (suatu bangsa bagi semua bangsa) dan keberadaannya semata-mata untuk semua bangsa (Kej. 12; Kel. 19:3-6). Misi dalam Perjanjian Lama bersifat sentripetal (pusaran-datanglah). Dalam Perjanjian Lama bangsa-bangsa dipanggil untuk menyembah Allah di Sion (sentripetal-pusaran). ${ }^{11}$

Gereja sebagai sekelompok orang yang telah dipanggil keluar dari dunia dan menjadi milik Allah memiliki tugas misi. Misi Gereja adalah untuk memuliakan Allah dengan melanjutkan pekerjaan Kerajaan Allah di dunia yang telah dimulai oleh Yesus (Mat. 5:16). Hal itu menuntut Gereja untuk melakukan pelayanan yang lebih luas, untuk menyampaikan Kabar Baik kepada orang-orang miskin, untuk memberitakan pembebasan kepada orang-orang tawanan dan penglihatan bagi orang-orang buta, untuk membebaskan orang-orang yang tertindas, untuk memberitakan tahun rahmat Tuhan telah datang (Luk. 4:18-19). ${ }^{12}$

\section{Pengertian Politik}

\section{$\underline{\text { Terminologi Istilah Politik }}$}

Kata politik berasal dari bahasa Belanda politiek dan bahasa Inggris

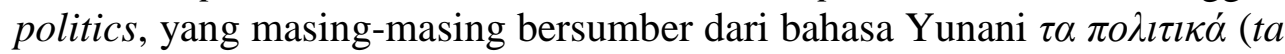

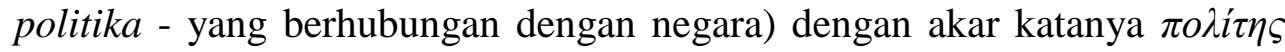
(polites - warga negara) dan $\pi$ ó $\imath \varsigma$ (polis - negara kota).

Secara etimologi kata politik masih berhubungan dengan polisi, kebijakan. Kata politis berarti hal-hal yang berhubungan dengan politik. Kata politisi berarti orang-orang yang menekuni hal politik. Kata politik berasal dari bahasa Yunani yaitu polis yang berarti kota atau negara kota. Turunan dari kata tersebut yaitu: Polites berarti warga negara. Politikos berarti kewarganegaraan. Politike tehne berarti kemahiran politik. Politike episteme berarti ilmu politik. Kata ini berpengaruh ke wilayah Romawi sehingga bangsa Romawi memiliki istilah ars politica yang berarti kemahiran tentang masalah-masalah kenegaraan.

Kata politik pun dikenal dalam bahasa Arab dengan kata siyasah yang berarti mengurus kepentingan seseorang. Pengarang Kamus Al Muhith

\footnotetext{
${ }^{11}$ Rainer Scheunemann dan Carolis Huwae, Misi \& Penginjilan..., 21

12 John R.W. Stott, Johannes Verkuyl, dkk, Misi Menurut Perspektif Alkitab, (Jakarta: Yayasan Komunikasi Bina Kasih, 2013), 163
} 
menjelaskan bahwa sustu ar-ra'iyata siyasatan berarti saya memerintahnya dan melarangnya. Jadi kata politik secara terminologis dapat diartikan:

a) Menunjuk kepada "satu segi kehidupan manusia bersama dengan masyarakat". Lebih mengarah pada politik sebagai usaha untuk memperoleh kekuasaan, memperbesar atau memperluas serta mempertahankan kekuasaan (politics). Misal: kejahatan politik, kegiatan politik, hak-hak politik.

b) Menunjuk kepada "satu rangkaian tujuan yang hendak dicapai" atau "cara-cara atau arah kegiatan tertentu untuk mencapai tujuan tertentu". Lebih mengarah pada kebijakan (policy). Misal: politik luar negeri, politik dalam negeri, politik keuangan.

c) Menunjuk pada pengaturan urusan masyarakat dalam segala aspek kehidupan. Pemerintah mengatur urusan masyarakat, masyarakat melakukan koreksi terhadap pemerintah dalam melaksanakan tugasnya (siyasah). ${ }^{13}$

\section{Pengertian Politik Menurut Para Ahli}

\section{a) Aristoteles}

Pengertian kata politik menurut Aristoteles adalah usaha yang ditempuh warga negara untuk mewujudkan kebaikan bersama.

\section{b) Prof. Miriam Budiardjo}

Pengertian politik menurut Prof. Miriam Budiardjo adalah macammacam kegiatan dalam suatu sistem politik (negara) yang menyangkut proses menentukan tujuan-tujuan dari sistem itu dan melaksanakan tujuan-tujuan itu.

c) Franz Magnis Suseno

Pengertian politik menurut Franz Magnis Suseno adalah segala kegiatan manusia yang berorientasi kepada masyarakat secara keseluruhan atau yang berorientasi kepada negara.

d) Ibnu Aqil

Pengertian politik menurut Ibnu Aqil adalah hal-hal praktis yang lebih mendekati kebaikan bagi manusia, dan lebih jauh dari kerusakan.

\section{e) Rod Hague}

Pengertian politik menurut Rod Hague adalah kegiatan yang menyangkut cara bagaimana kelompok-kelompok mencapai keputusan-keputusan yang bersifat kolektif dan mengikat dengan usaha untuk mendamaikan perbedaan-perbedaan diantara anggota-anggotanya.

\section{f) Ossip K. Flechtiem}

Pengertian politik menurut Ossip K. Flechtiem adalah ilmu sosial yang khusus mempelajari sifat dan tujuan dari negara, sejauh negara

\footnotetext{
${ }^{13}$ https://id.wikipedia.org/wiki/Politik\#Etimologi
} 
merupakan organisasi kekuasaan, dan sifat serta tujuan gejala-gejala kekuasaan lain yang tak resmi yang dapat mempengaruhi negara.

g) Seely dan Stephen Leacock

Pengertian politik menurut Seely dan Stephen Leacock adalah ilmu yang cocok menangani pemerintahan.

h) Adolf Grabowsky

Pengertian politik menurut Adolf Grabowsky adalah menyelidiki negara dalam keadaan bergerak.

i) Litre

Pengertian politik menurut Litre adalah ilmu memerintah dan mengatur negara

\section{j) Sri Sumantri}

Pengertian politik menurut Sri Sumantri adalah pelembagaan dari hubungan antar manusia yang dilembagakan dalam bermacam-macam badan politik, baik itu suprastruktur politik maupun infrastruktur politik.

k) Wilbur White

Pengertian politik menurut Wilbur White adalah ilmu yang mempelajari tentang asal mula, bentuk-bentuk dan proses-proses negara dan pemerintah.

\section{l) Kartini Kartolo}

Pengertian politik menurut Kartini Kartolo adalah aktivitas perilaku atau proses yang menggunakan kekuasaan untuk menegakkan peraturanperaturan dan keputusan-keputusan yang sah dan berlaku di tengah masyarakat.

\section{m) Carl Schmidt}

Pengertian politik menurut Carl Schmidt adalah suatu dunia yang didalamnya orang-orang lebih membuat keputusan-keputusan daripada lembaga-lembaga yang abstrak.

n) Cheppy H. Cahyono

Pengertian politik menurut Cheppy H. Cahyono adalah macam-macam kegiatan dalam sistem politik atau Negara yang menyangkut dengan proses menentukan dan sekaligus melaksanakan tujuan-tujuan sistem tersebut.

o) Ramlan Surbakti

Pengertian politik menurut Ramlan Surbakti adalah proses interaksi antara pemerintah dan masyarakat untuk menentukan kebaikan bersama bagi masyarakat yang tinggal dalam suatu wilayah tertentu.

\section{p) F. Isjwara}

Pengertian politik menurut $\mathrm{F}$. Isjwara adalah salah satu perjuangan untuk mendapatkan kekuasaan atau sebagai teknik menjalankan kekuasaankekuasaan.

q) Paul Janet 
Pengertian politik menurut Paul Janet adalah ilmu yang mengatur perkembangan Negara dan juga prinsip-prinsip pemerintahan.

r) Harold Laswell

Pengertian politik menurut Harold Laswell adalah ilmu yang mempelajari tentang pembentukan dan pembagian kekuasaan.

s) Robert

Pengertian politik menurut Robert adalah seni memerintah dan mengatur masyarakat manusia.

\section{t) W.A Robson}

Pengertian politik menurut W.A. Robson adalah ilmu yang mempelajari tentang kekuasaan dalam masyarakat, yakni sifat hakiki, dasar, prosesproses, ruang lingkup dan hasil-hasil.

\section{u) Andrew Heywood}

Pengertian politik menurut Andrew Heywood adalah kegiatan suatu bangsa yang bertujuan untuk membuat, mempertahankan serta mengamandemen peraturan-peraturan umum yang mengatur kehidupannya, yang artinya tidak dapat terlepas dari gejala konflik dan kerjasama.

\section{v) Roger F. Soltau}

Pengertian politik menurut Roger F. Soltau adalah ilmu yang mempelajari tentang Negara, tujuan-tujuan Negara, dan lembagalembaga Negara yang akan melaksanakan tujuan tersebut dan hubungan antara Negara dengan warga negaranya serta Negara lain.

w) Johan Kaspar Blunchli

Pengertian politik menurut Johan Kaspar Blunchli adalah ilmu yang memperhatikan masalah kenegaraan, dengan memperjuangkan pengertian dan pemahaman tentang negara dan keadaannya, sifat-sifat dasarnya dalam berbagai bentuk atau manifestasi pembangunannya.

\section{x) Joice Mitchel}

Pengertian politik menurut Joice Mitchel adalam pengambilan keputusan kolektif atau pembuatan kebijaksanaan umum masyarakat seluruhnya. ${ }^{14}$

Berdasarkan terminologi kata politik dan pendefinisian berdasarkan pendapat beberapa para ahli politik di atas, dapat dikatakan bahwa sesungguhnya politik bertujuan mulia, yakni untuk kesejahteraan bersama dari anggota masyarakat atau warga negara. Karena itu sangatlah penting kehadiran Gereja dalam menyampaikan misi Allah dalam negara lewat bidang politik, karena tujuan politik searah dengan tujuan Allah, yakni

\footnotetext{
${ }^{14} \mathrm{http} / / /$ www.pengetahuan.com/2017/06/pengertian-politik-menurut-para-ahliterlengkap.html
} 
memuliakan Allah dan membawa syalom bagi manusia, masyarakat, bangsa dan negara.

\section{Situasi/Kondisi Politik Di Indonesia}

Menurut Ciptawilangga dkk, hal lain yang juga perlu diperhatikan adalah kondisi politik di Indonesia. Bagaimana situasi politik saat ini? Apakah perkembangan agama Kristen di Indonesia mendapat jaminan keamanan yang serius dari pemerintah? Apakah keberlangsungan kehidupan umat Kristen mendapat perhatian yang besar dari pemerintah saat ini? Kondisi politik yang berubah setiap saat tentu perlu dicermati bersama. ${ }^{15}$ Untuk bermisi bagi bangsa ini perlu pencermatan seperti yang diungkapkan oleh Ciptawilangga dkk, sehingga misi Allah dapat disampaikan dengan tepat untuk menjawab kebutuhan bangsa ini.

Dalam bukunya, Octavianus menuliskan bahwa politik di Indonesia adalah politik tanpa prinsip, yang mana hal tersebut adalah:

a. Di Negara maju dalam pemilihan umum bila diumumkan partai pemenangnya, maka partai yang kalah akan segera mendukung partai yang menang tersebut (kedewasaan dalam berpolitik). Tetapi di Indonesia justru sebaliknya. Sepertinya belum terbiasa menerima kekalahan (ketidakdewasaan dalam berpolitik). Jika politik dengan prinsip kesejahteraan bangsa, bukan golongan, sepatutnya partai politik yang menang dalam pemilihan umum tersebut, programnya adalah kesejahteraan bangsa yang utama, bukan hanya partainya saja. Sebab jika bangsa sejahtera, dengan sendirinya golongan dan partainya pun sejahtera. Tetapi yang terjadi di negeri ini justru sebaliknya, kepentingan golongan dan partainya lebih diutamakan dari kepentingan bangsa. Akibatnya keadilan dan hukum sulit ditegakkan, terjadi Korupsi, Kolusi dan Nepotisme.

b. Tidak ada penegakan keadilan dan kebenaran. Keadilan dan kebenaran hanya berpihak kepada orang tertentu (penguasa tertentu, entah karena uang atau jabatannya), sedangkan rakyat biasa dihukum berat. Contoh: seorang pencuri ayam dihajar babak belur dan dihukum, sedangkan pelaku Korupsi, Kolusi dan Nepotisme diberikan hukuman tidak setimpal, bahkan untuk memprosesnya mengalami kesulitan.

15 Yunus Ciptawilangga dkk, Menang dalam Persaingan Gereja, (Jakarta: Metanoia Publishing, 2003), 39 
c. Di negara-negara yang politiknya disertai prinsip, akan terjadi sikap menghargai pluralitas tanpa memandang latar belakang etnis atau agama. Disintegrasi bangsa dapat dimulai dari politik tanpa prinsip ini. ${ }^{16}$

d. Kejahatan di bidang Politik. Berkenaan dengan kejahatan di bidang politik, Halim menuliskan beberapa jenis atau bentuk kejahatan, di antaranya: korupsi, kolusi, nepotisme, money politic, teroris, perang, perebutan kekuasaan, runtuhnya demokrasi, runtuhnya keadilan, kepentingan partai, bukan bangsa, ${ }^{17}$ penyalahgunakan jabatan, kekuasaan dan kedudukan atau wewenang untuk menyingkirkan orang lain (contoh dalam Perjanjian Lama, sikap Haman terhadap orang Yahudi). ${ }^{18}$ Sedangkan menurut Darmaputra, penyebab kejahatan ialah: persaingan yang tidak sehat, saling menjatuhkan, (supaya saya bisa hidup, yang lain mesti mati) manusia menjadi serigala bagi sesamanya, bukan supaya saya hidup yang lain juga harus hidup. ${ }^{19}$

Kejahatan lainnya di bidang politik rasial, ketidak-setaraan, penjajahan, upah yang terlalu rendah dan pengangguran, pertentangan antar kelompok, diskriminasi terhadap perempuan, ketidak-pastian ekonomi. ${ }^{20}$

e. Peperangan rohani di dunia politik yang membutuhkan misi Greja, yakni:

1) Dunia politik berhadapan dengan korupsi.

2) Dunia politik berhadapan dengan roh iri hati.

3) Dunia politik berhadapan dengan dunia gila hormat.

4) Dunia politik berhadapan dengan roh perzinahan.

5) Dunia politik berhadapan dengan roh pornografi. ${ }^{21}$

Mengamati situasi atau kondisi politik di Indonesia maka sangat pentinglah kehadiran orang percaya atau Gereja sebagai garam dan terang di tengah bangsa dan negara. Sesungguhnya negara membutuhkan kehadiran Gereja untuk menyampaikan misi Allah.

\footnotetext{
${ }^{16}$ Petrus Octavianus, Jilid I Menuju Indonesia Jaya (2005-2030) dan Indonesia Adidaya (2030-2055), (Batu: Departemen Literatur YPPII, 2005), 223-224

${ }^{17}$ Ibid., 45-46

${ }^{18}$ Makmur Halim, Terror, Terroris, dan Terrorisme, (Batu: Shalom Publisher), 75 76

${ }^{19}$ Eka Darmaputra, 365 Anak Tangga Menuju Hidup Berkemenangan, (Jakarta: BPK Gunung Mulia, 2006), 211-212

${ }^{20}$ Ibid., 211-240

21 Petrus Octavianus, Gereja Memasuki Abad XXI, (Batu: YPPII Departemen Literatur, 1998), 120-122
} 


\section{$\underline{\text { Ruang Lingkup Politik }}$}

Politik berbicara mengenai hal-hal yang berkaitan dengan:

\section{Masyarakat}

Menurut Robert MacIver, masyarakat adalah suatu sistem hubungan yang ditertibkan. Selanjutnya Harold J. Laski menambahkan bahwa masyarakat adalah sekelompok manusia yang hidup bersama dan bekerjasama untuk mencapai/terkabulnya keinginan-keinginan mereka bersama. Dalam masyarakat tersebut, setiap orang menginginkan beberapa nilai seperti: Kekuasaan, Pendidikan atau Penerangan, kekayaan, kesehatan, keterampilan, kasih sayang, kejujuran, dan keadilan, serta keseganan atau respek. Dalam tujuan UUD 1945 tercapainya masyarakat adil dan makmur. Jika pemangku kekuasaan politik dan negara tidak memperhatikan harapan dan kebutuhan masyarakat tersebut; maka akan terjadi ketegangan dan melahirkan konflik-konflik baru yang menuju kepada hancurnya keutuhan dalam suatu masyarakat. ${ }^{22}$

\section{Negara}

Negara merupakan suatu organisasi dalam suatu wilayah yang memiliki suatu kekuasaan tertinggi yang yang ditaati oleh rakyatnya. Boleh dikatakan negara merupakan organisasi politik yang paling utama dalam suatu wilayah berdaulat. ${ }^{23}$ Negara memiliki dua arti, yaitu: pertama, negara adalah masyarakat atau wilayah yang merupakan satu kesatuan polis. Dan kedua, Negara adalah lembaga pusat yang menjamin kesatuan polis tersebut, yang menata, dengan demikian menguasai wilayah tersebut. Negara wajib memajukan kepentingan-kepentingan masyarakat dengan seoptimal mungkin, berdasarkan solidaritas seluruh masyarakat, dengan menjamin kebebasan para anggota masyarakat dari campur tangan yang sewenang-wenang, dan atas dasar prasyarat keadilan. Negara juga memiliki kekuasaan yang besar. Tetapi kekuasaan itu harus tetap berdasar dan bertujuan kepada bentuk kesejahteraan semua golongan dalam masyarakat. Negara jangan pernah menggunakan tangan besi dan dapat diperalat oleh oknum dan golongan tertentu untuk mencapai keinginan mereka dan

\footnotetext{
${ }^{22}$ Jimmy Rungkat, Theologi Politik Yesus..., 31

23 Heri Herdiawanto \& Jumanta Hamdayama, Cerdas, Kristis, dan Aktif Berwarganegara, (Jakarta: Penerbit Erlangga,), 111
} 
merusak kesatuan dan persatuan bangsa yang berdasarkan Pancasila dan UUD 1945 sebagai dasar dan falsafah Negara.

Dalam sejarah ada tiga sokoguru filsafat negara, yakni: i). Negara tidak berhak menuntut ketaatan mutlak, manusia harus lebih taat kepada Allah dari pada kepada manusia; ii). bahwa negara dalam menjalankan tugasnya tidak terikat pada norma-norma etis di mana ide keadilan adalah paling dasar; iii). bahwa kekuasaan negara harus mengalir melalui jalurjalur sistem hukum. Indonesia adalah negara yang berdasarkan atas hukum dan pembagian kekuasaan (trio political: legislatif, eksekutif, dan yudikatif), tidak berdasarkan kekuasaan tunggal. Bentuk kekuasaan negara harus dibangun atas dasar faktor dedikasi. Negara yang melayani masyarakat adalah negara yang berkuasa. Negara dibangun oleh dan dari berbagai golongan, segala keputusan negara harus berdasarkan suara bersama dan untuk kebaikan bersama, bukan suara terbanyak untuk kepentingan golongan politik tertentu. ${ }^{24}$

\section{Demokrasi}

Kata demokrasi berasal dari dua kata Yunani, yitu: Demos yang berarti "rakyat" dan kratos atau kratein yang berarti "kekuasaan". Berdasarkan etimologi kata tersebut, demokrasi berarti "rakyat yang berkuasa". Di Indonesia menganut demokrasi konstitusional (demokrasi Pancasila), di mana pemerintah yang demokratis adalah pemerintah yang tidak boleh bertindak sewenang-wenang terhadap warga negaranya dan pembatasan atas kekuasaan pemerintah tercantum dalam konstitusi, yang disebut "pemerintah berdasarkan konstitusi". Sistem demokrasi menjamin kebebasan hak setiap individu untuk menjalankan segala sesuatu tanpa ditekan, namun kebebasan hak itu pun harus dibarengi dengan kewajibannya dalam suatu negara. Kewajiban itu pun bukan suatu tekanan, tetapi merupakan suatu pagar bagi kebebasan setiap individu. Demokrasi yang dimaksud adalah demokrasi yang beretika dan bermoral, bukan membabi-buta atau kebablasan. Supaya pelaksanaan demokrasi dapat terealisasi dengan baik dan benar sesuai maksud dan pengertiannya, maka perlu pendidikan politik tentang demokrasi kepada setiap warga negara, sehingga setiap warga negara dapat mengontrol dirinya dan juga pemerintah dalam berpolitik yang demokrasi, bukan demo-crazy. ${ }^{25}$

\section{Hak Asasi Manusia}

\footnotetext{
${ }^{24}$ Jimmy Rungkat, Theologi Politik..., 32

${ }^{25}$ Ibid., 32-34
} 
Bangsa yang secara nyata menghormati hak-hak segenap anggotanya sebagai manusia itulah bangsa yang beradab dan adil. Oleh karena itu hakhak azasi manusia tidak hanya mengenai kebebasan masing-masing orang, melainkan juga mengenai partisipasi mereka dalam menentukan kehidupan bersama, perlakuan wajar di depan hukum, mendapat perlakuan dan penghidupan yang layak secara sosial ekonomi, dan menghargai budaya mereka. Di Indonesia, jaminan atas hak azasi manusia itu meliputi: hak atas kebebasan untuk mengeluarkan pendapat (UUD1945, pasal 28), hak atas kedudukan yang sama di hadapan hukum (UUD 1945, pasal 27 ayat 1), hak kebebasan berkumpul (UUD 1945, pasal 28), hak atas kebebasan beragama (UUD 1945 pasal 29 ayat 1 dan 2), hak atas penghidupan yang layak (UUD 1945 pasal 27 ayat 2), hak atas kebebasan berserikat (UUD, pasal 28) dan hak atas pengajaran (UUD 1945, pasal 31 ayat 1 dan 2). ${ }^{26}$

\section{Partai Politik}

Berikut ini adalah partai-partai yang memenuhi persyaratan berdasarkan Undang-undang untuk mengikuti Pemilihan Umum pada tahun 2014.

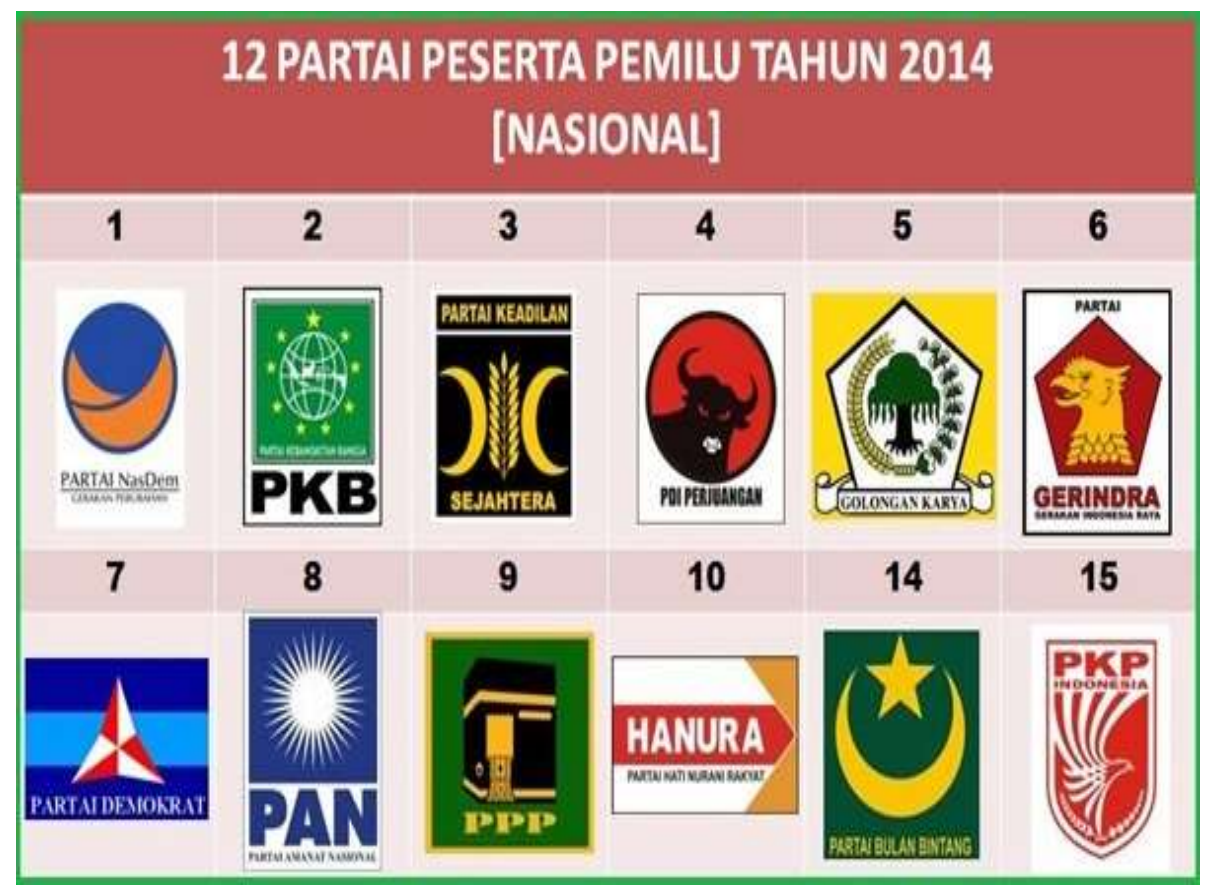

${ }^{26}$ Jimmy Rungkat, Theologi Politik..., 35-36 
Partai politik lahir atas dasar demokrasi, di mana rakyat merupakan bagian yang sangat penting dalam proses politik. Melalui partai politik, rakyat melaksanakan haknya untuk menentukan para pemimpin bangsa yang akan menjalankan kehidupan bangsa dalam menentukan kebijakan umum demi kesejahteraan rakyat. Pembentukan partai politik harus memperhatikan kondisi masyarakat suatu negara di mana partai politik itu berada. Kalau masyarakat itu homogen, maka partai yang dibentuk itu pun dapat homogen, tetapi jika masyarakat bangsa itu heterogen, maka partai politik yang dibentuk harus heterogen. Dapat dipahami bahwa partai politik yang cocok di Indonesia sebagai bangsa yang heterogen dan pluralistik adalah partai yang bersifat nasionalis dan pancasilais, bukan berlebel atau berbasis homogen atau golongan tertentu (agama, suku dll). Setiap partai harus dewasa dalam berpolitik, berpolitik yang bersih, baik dan benar, tidak politik uang, tidak bisnis politik, tidak dendam politik, siap menerima kekalahan dan dapat bekerja sama dengan partai pemenang pemilu, harus tetap membangun komunikasi politik, saling mendukung, demi kesejahteraan rakyat, bukan demi kepentingan partai dan golongan atau agama tertentu. $^{27}$

\section{Penyelenggara Negara (Legislatif, Eksekutif, Yudikatif)}

1) Legislatif (DPR, MPR, DPR Propinsi, Kabupaten kota). Membuat Undang-undang dan mengontrol pemerintah.

2) Eksekutif (Presiden, wakil presiden, para mentri dan para kepala daerah), menjalankan Undang-undang dan pemerintahan negara.

3) Yudikatif (ABRI, Kehakiman, Kejaksaan dan Kepolisian). Menjalankan Undang-ungang dan penegakan hukum dan keamanan. ${ }^{28}$

Misi orang percaya atau Gereja harus mewarnai setiap ruang lingkup politik. Sehingga setiap ruang lingkup tersebut tetap berfungsi sesuai dengan maksud dan tujuannya dalam negara. Gereja harus hadir untuk mengawal pelaksanaan setiap ruang lingkup politik dengan suara kenabiannya. Selain itu Gereja juga dapat memberikan pencerahan politik kepada warga Gereja sehingga warga Gereja sebagai warga negara tidak dibodohi dan bertindak salah di tengah bangsa dan negara. Dengan itu orang percaya sebagai warga Gereja yang adalah warga negara dapat menyatakan misi Allah bagi bangsa dan negaranya.

${ }^{27}$ Jimmy Rungkat, Theologi Politik..., 36-37

${ }^{28}$ Stevri Indra Lumintang, Re-Indoneianisasi Bangsa, (Batu: Departemen Multi Media YPPII, 2009), 391-392 


\section{$\underline{\text { Tujuan Misi Gereja Berkenaan dengan Politik }}$}

\section{Memuliakan Allah}

Tujuan utama misi dalam bidang politik adalah untuk memuliakan Allah. Karena Allah menciptakan manusia sebagai makhluk politik untuk memuliakan Dia. ${ }^{29}$

\section{Membawa Syalom}

Darmaputera mengartikan, Syalom adalah: Damai dalam arti yang sepenuh-penuhnya. Ketika manusia mengalami kehidupan yang utuh dan penuh, lahir dan batin. Yesaya menggambarkan suasana itu sebagai keadaan, di mana anak domba bermain-main dengan singa, dan anak kecil memasukkan tangannya ke lubang ular, tanpa kuatir cedera. ${ }^{30}$

\section{Tugas Gereja dalam Misi dan Politik}

Berdasarkan Roma 13:1-3, Halim menuliskan bahwa: setiap warga negara memiliki tanggungjawab politik, dan juga sebaliknya pemerintah juga memiliki tanggungjawab terhadap rakyatnya untuk menegakkan keadilan dan keamanan serta mengatasi semua teror-teror yang besifat politik maupun agama. Pemerintah juga harus menindak tegas pelakupelaku teror yang keji. Pemerintah memiliki hati hurani yang baik dan benar. $^{31}$ Ciptawilangga menyarankan, Gereja perlu terus-menerus mengikuti perkembangan politik. Gereja harus mulai melihat keluar jendela, bahkan mungkin ikut aktif dalam kegiatan politik, seyogyanya Gereja tidak hanya pasif menerima apa pun keputusan pemerintah, tetapi secara aktif memberi sumbang saran bagi perkembangan agama di Indonesia. ${ }^{32}$ Tugas Gereja adalah mengarahkan setiap umat Kristen untuk mempergunakan hak pilih mereka sebaik-baiknya dan secara bertanggung jawab. ${ }^{33}$

\footnotetext{
${ }^{29}$ Stevri Indra Lumintang, Re-Indoneianisasi ..., 101-102

${ }^{30}$ Eka Darmaputra, 365 Anak Tangga Menuju ..., 221-222

${ }^{31}$ Makmur Halim, Terror, Terroris ..., 68-69

${ }^{32}$ Yunus Ciptawilangga dkk, Menang dalam Persaingan Gereja..., 39

${ }^{33}$ Jimmy Rungkat, Theologia Politik Yesus..., 17
} 
Berkaitan dengan pemilihan dan dukungan terhadap pemimpin bangsa secara khusus Presiden, Gereja harus memberikan wawasan kebangsaan kepada warga Gereja untuk memilih manusia sentral, seperti yang diungkapkan Octavianus dalam tulisannya: "Dalam politik diperlukan manusia sentral untuk memimpin bangsa Indonesia". Manusia sentral yang dimaksud ialah seorang Presiden yang dapat berdiri di atas kepelbagaian, seorang yang dapat melepaskan diri dari kepentingan partainya sendiri, dan kepemimpinan partainya untuk mengabdi kepada seluruhnya. Ia seorang yang tegas terhadap tindakan korupsi dan kekerasan, menjalankan hukum tanpa memandang bulu, demi kepentingan bangsa dan negara. Seorang yang mengutamakan kesejahteraan rakyat yang merata dari Sabang sampai Merauke, dari Sangir sampai Pulau Rote. Ia seorang yang mengerti prinsipprinsip global, seorang yang berpengalaman luas, memiliki pengetahuan global, dan dapat diterima dunia sebagai manusia sentral. ${ }^{34}$

\section{Ajaran Misi Gereja bagi Negara agar Memiliki dan Menerapkan Prinsip Politik yang Benar}

Prinsip utama tentulah politik untuk memuliakan Allah. Dalam tulisannya Octavianus menuliskan 3 prinsip politik yang benar, yakni: (1) Membawa sejahtera bagi seluruh rakyat Indonesia. (2) Kemajuan ekonomi dan kecerdasan bagi setiap warga negara. (3) Menerima dan menghargai kemajemukan sebagai kekayaan bangsa. ${ }^{35}$

Selanjutnya Rungkat menuliskan, bahwa prinsip politik berdasarkan Theologi Politik Yesus adalah:

a. Prinsip Kemuliaan Allah: Segala sesuatu dari DIA, oleh DIA dan kepada DIA. Bagi DIA-lah kemuliaan sampai selama-lamanya.

b. Prinsip Kedaulatan Allah: Allah yang berdaulat dan berkuasa di Sorga dan di bumi.

c. Prinsip Dedikasi: Seluruh kehidupan didedikasikan untuk Tuhan.

d. Prinsip Simpati dan empati dalam kasih: Kasih kepada Allah dan sesama. $^{36}$

\section{$\underline{\text { Saran Misi yang Perlu Diberikan Gereja bagi Para Politikus }}$}

a. Supaya mempunyai interest iman. Perlu mendengarkan suara Tuhan terlebih dahulu, baru mengambil keputusan politik.

\footnotetext{
${ }^{34}$ Petrus Octavianus, Jilid I Menuju Indonesia Jaya...,300-301

${ }^{35}$ Ibid., 224-225

${ }^{36}$ Jimmy Rungkat, Theologia Politik Yesus.., 101-106
} 
b. Mengakui kedaulatan Allah sebagai yang tertinggi. Mempercayakan diri secara total kepada kekuasaan Allah.

c. Menghormati dan menaati Dasar Negara dan perundang-undangan yang berlaku.

d. Mengakui dan menerima Pluralitas. Indonesa bangsa yang beragam atau majemuk. $^{37}$

\section{PERAN DAN STRATEGI MISI GEREJA LEWAT POLITIK DI INDONESIA}

\section{Peran Gereja dalam Misi Lewat Politik di Indonesia}

a. Pilih pemimpin yang berjiwa nasionalis, memiliki komitmen terhadap Negara Kesatuan Republik Indonesia dan Pancasila.

b. Pilih pemimpin yang memiliki integritas kepribadian yang tinggi dan moral yang mulia.

c. Pilih pemimpin yang menghargai kemajemukan agama, budaya dan ras.

d. Pilih pemimpin yang memiliki kecerdasan intelektual, emosional dan spiritual yang kuat, serta kecakapan memimpin yang handal.

e. Mendorong jemaat yang memiliki kemampuan berpolitik untuk terlibat dalam partai dan parlemen.

f. Memperlengkapi jemaat dengan pengetahuan dan keterampilan politik dan hukum dalam perspektif kristiani.

g. Memperlengkapi politisi Kristen dengan pembentukan karakter, sehingga bermoral kristiani.

h. Mendukung dan mendampingi tokoh atau pemimpin dan ahli hukum Kristen walaupun mungkin bukan anggota jemaat sendiri. ${ }^{38}$

\section{$\underline{\text { Startegi Misi Gereja Lewat Politik Di Indonesia }}$}

Menurut Octavianus, Pancasila secara keseluruhan, maupun butir demi butir, kelima butir dalam Pancasila jelas tidak menentang Alkitab. ${ }^{39}$

${ }^{37}$ Petrus Octavianus, Gereja Memasuki Abad XXI..., 123-130

${ }^{38}$ Stevri Indra Lumintang, Misiologia Kontemporer, (Batu: Departemen Literatur PPII, 2006), 332-333 
Maka dengan itu Pancasila dan Undang-Undang Dasar 1945 dapat dijadikan jembatan untuk menyampaikan berita syalom, misi Allah. Dalam misi tentulah Alkitab sebagai sumber dan dasar theologi misi Kristen. Tetapi berkaitan dengan pelaksanan misi di tengah Bangsa dan Negara, Undang-Undang Dasar 1945 dan Pancasila merupakan jembatan yang sangat efektif.

\section{Pancasila}

1) Ketuhanan Yang Maha Esa.

2) Kemanusiaan yang Adil dan Beradab.

3) Persatuan Indonesia.

4) Kerakyatan yang dipimpin oleh hikmat kebijaksanaan dalam permusyawaratan perwakilan.

5) Keadilan Sosial bagi Seluruh Rakyat Indonesia.

\section{Undang-Undang Dasar 1945}

Pelajari terlebih dahulu setiap pasal dalam UUD 1945 lalu bangun jembatan misi dengan menggunakan istilah dalam UUD 1945 untuk menyampaikan misi Allah.

\section{Nilai-nilai Hidup Berbangsa dan Bernegara}

Menurut Lase, dalam menjalankan misi Allah di tengah Bangsa dan Negara melalui bidang politik, Gereja atau orang percaya perlu memiliki dan memperhatikan nilai-nilai sosial politik yang searah dengan maksud firman Tuhan. Nilai-nilai itu sangat tepat digunakan dalam konteks misi karena memakai istilah umum yang mudah diterima oleh masyarakat umum dan tidak berbenturan dengan nilai-nilai kebangsaan dan keagamaan. Beberapa nilai yang perlu diperhatikan oleh orang percaya mewujudkan tanggungjawab misinya melalui bidang sosial politik di Indonesia, antara lain:

${ }^{39}$ Petrus Octavianus, Mengapa Umat Kristen Menerima Pancasila Sebagai Azas Tunggal dalam Hidup Bernegara, Berbangsa, Bermasyarakat, (Batu: Departemen Literatur YPPII, 1985), 13 


\section{1) Kebebasan}

Kebebasan berbicara, berkumpul, dan berserikat, kebebasan beragama dan berkeyakinan, kebebasan untuk memilih pekerjaan, tempat tinggal, dan kewarganegaan.

\section{2) Kemerdekaan}

Merdeka dari ketakutan, penindasan dan cengkeraman pihak manapun.

\section{3) Kerendahan hati}

Tidak menyombongkan diri, tidak merendahkan orang lain, sikap mendengar dan melayani.

\section{4) Ketulusan}

Berani menerima kenyataan, termasuk menerima kekalahan, perkataan harus sesuai dengan perbuatan, dan tidak menyembunyikan niat buruk di balik perhatian.

\section{5) Kejujuran}

Menyatakan benar untuk hal yang benar dan menyatakan salah untuk hal yang salah, objektif dan berani mengakui kekurangan.

\section{6) Kepeloporan}

Kesiapan mengambil prakarsa untuk meningkatkan prestasi demi kepentingan bersama.

\section{7) Kebenaran}

Kebenaran dengan berpedoman pada 3 (tiga) sumber kebenaran, yaitu: a. kebenaran Tuhan yang abadi. b. Kebenaran akademik yang senantiasa dikaji ulang sesuai dengan perkembangan dan penemuan baru, dan c. Kebenaran konsesus yang merupakan hasil kesepakatan nasional bangsa Indonesia.

\section{8) Kasih}

Mengasihi manusia seperti diri sendiri, mengakui bahwa semua manusia adalah saudara, sebagai manusia yang diciptakan oleh Allah sesuai dengan citra-Nya.

\section{9) Kesamaan}

Semua manusia mempunyai martabat dan hak-hak yang sama, yaitu: hak asasi manusia. Semua warga berkedudukan sama sebagai warga negara dan bangsa, baik di hadapan hukum, maupun pemerintah.

10) Keadilan

Setiap warga negara berhak mendapatkan perlakuan yang adil, negara harus berlaku adil kepada semua warga negaranya, negara harus menjamin agar setiap warga negara mendapatkan keadilan, negara dapat dikatakan adil kalau setiap warga negara mendapatkan apa yang menjadi hak-haknya, antara lain: Hak Asasi Manusia (HAM), hak negara, dan hak imbalan atas prestasi kerjanya.

\section{1) Kebangsaan}


Menyadari dan meyakini bahwa kita adalah bagian dari bangsa Indonesia yang senasib sepenanggungan dengan kelompok-kelompok masyarakat lainnya. Meyakini bahwa bersama-sama dengan kelompok masyarakat lain mempunyai cita-cita nasional, masyarakat adil dan makmur berdasarkan Pancasila.

\section{2) Kesetiaan}

Setia menjalankan tugas yang dipercayakan, setia kepada bangsa dan negara.

\section{3) Kesetiakawanan}

Bersikap empati terhadap kesuksesan dan kegagalan orang lain, setia kepada kawan, tetangga, dan masyarakat, terutama saat mereka menderita kesusahan, suka menolong orang yang kesusahan. ${ }^{40}$

\section{SIMPULAN}

Misi adalah tugas yang diberikan oleh Tuhan Yesus kepada orang percaya atau Gereja untuk pergi dan bersaksi melintasi tapal batas budaya untuk menyampaikan kabar sukacita (syalom) di tengah masyarakat, bangsa dan negara secara holistik tentang Tuhan Yesus Kristus Juruselamat dunia. Gereja adalah umat Allah yang dipanggil keluar dari kegelapan dan menjadi milik Allah untuk menjadi utusan dan saksi Allah di dalam dunia. Politik adalah ilmu untuk memerintah dan mengatur negara oleh pemerintah, untuk mencapai kebaikan bersama demi mencapai masyarakat yang sejahtera (syalom).

Situasi dan kondisi politik di Indonesia belum stabil, hal itu ditandai dengan adanya pelaksanaan politik yang tidak sehat, seperti: politik uang, kampanye hitam, korupsi, kolusi dan nepotisme politik. Ruang lingkup politik terdiri dari: Masyarakat, negara, demokrasi, hak asasi manusia, partai politik dan penyelenggara negara (eksekutif, legislatif dan yudikatif). Tujuan misi Gereja berkaitan dengan politik ialah memuliakan Allah dan membawa syalom di tengah bangsa dan negara. Tugas Gereja berkaitan dengan misi dan politik ialah Gereja harus ikut berpartisipasi dengan memberikan ide, pikiran dan gagasan bagi negara, dan memberikan pemahaman kepada warga Gereja agar ikut berpartisipasi dalam mendukung terciptanya politik yang sehat dalam kehidupan bangsa, memilih pemimpin yang takut akan Tuhan dan berjiwa nasionalis, taat kepada Pancasila dan Undang-Undang Dasar 1945. Gereja harus membangun strategi misi melalui Pancasila, Undang-Undang Dasar 1945 sebagai sarana untuk menyampaikan misi Allah, karena keduanya sejalan

${ }^{40}$ Jason Lase, Pendidikan Agama Kristen, (Bandung: 193-195) 
dengan maksud firman Allah, dan dengan tidak mengabaikan nilai-nilai kehidupan berbangsa dan bernegara.

Tujuan politik adalah semata-mata untuk kesejahteraan rakyat. Hal itu searah dengan tujuan Allah dalam misi-Nya untuk memuliakan Allah dan menghadirkan syalom bagi bangsa-bangsa, temasuk bangsa Indonesia.

Dari seluruh paparan di atas, maka penulis memberi rekomendasi bagi gereja sebagai berikut:

1) Gereja sebagai agen tunggal misi Allah dalam dunia, perlu hadir untuk menyerukan suara kenabian dengan ide, gagasan dan pemikirannya bagi pembangunan bangsa dan negara.

2) Gereja harus hadir untuk mengawal jalannya roda pemerintahan yang sehat demi kemakmuran rakyat.

3) Gereja dapat bermisi secara holistik dalam segala bidang dan segi hidup bangsa (jasmani dan rohani), termasuk melalui bidang politik.

4) Gereja perlu meneruskan semangat dan pemikiran para tokoh Kristen, seperti T.B Simatupang, Petrus Octavanus dan yang lainnya bagi pembangunan bangsa Indonesia seutuhnya.

\section{DAFTAR PUSTAKA}

Bosch, David J.,

2000 Transformasi Misi Kristen: Sejarah Teologi Misi yang Mengubah dan Berubah. Jakarta: BPK Gunung Mulia.

Ciptawilangga, Yunus dkk,

2003 Menang dalam Persaingan Gereja. Jakarta: Metanoia Publishing.

Darmaputera, Eka

2006365 Anak Tangga Menuju Hidup Berkemenangan. Jakarta: BPK Gunung Mulia.

Glasser,Arthur F., Donald A. McGavran,

1983 Contemporary Theologies of Mission. Grand Rapins: Baker Book House.

Hadiwijono, Harun

2001 Iman Kristen. Jakarta: BPK Gunung Mulia. 
Halim, Makmur

Tt Terror, Terroris dan Terrorisme. Penerbit: James Steven, Shalom Publishers.

Herdiawanto, Heri \& Jumanta Hamdayama,

Tt Cerdas, Kritis, dan Aktif Berwarganegara. Jakarta: Penerbit Erlangga.

Lase, Jason

Tt Pendidikan Agama Kristen, Bandung: 193-195

Lumintang, Stevri Indra

2009 Re-Indoneianisasi Bangsa. Batu: Departemen Multi Media YPPII.

2006 Misiologia Kontemporer. Batu: Departemen Literatur YPPII.

Octavianus, Petrus

2005 Menuju Indonesia Jaya (2005-2030) Dan Indonesia Adidaya (2030-2055). Batu: Departemen Literatur YPPII.

1998 Gereja Memasuki Abad XXI. Batu: YPPII Departemen Literatur.

1985 Mengapa Umat Kristen Menerima Pancasila sebagai Azas Tunggal dalam Hidup Bernegara, Berbangsa, Bermasyarakat. Batu: Departemen Literatur YPPII.

Peters, George W.,

1974 A Biblical Theology of Missions. Chicago: Moody Press.

Ruck, John, dkk,

2011 Jemaat Misioner. Jakarta: Yayasan Komunikasi Bina Kasih.

Rungkat, Jimmy

2010 Theologia Politik Yesus. Batu: Departemen Literatur YPPII.

Scheunemann, Rainer dan Carolis Huwae, 
2006 Misi \& Penginjilan. Papua: Sekolah Alkitab Malam Gereja Kristen Injili di Tanah Papua.

Stott, John R. W.,

1975 Christian Mission in the Modern Word. London: Intervarsity Press.

Stott, John R.W., Johannes Verkuyl, dkk,

2013 Misi Menurut Perspektif Alkitab. Jakarta: Yayasan Komunikasi Bina Kasih.

Thiessen, Henry C.,

2000 Teologi Sistematika. Malang: Gandum Mas.

Van Engen,Charles

1996 Mission on the Way: Issues in Mission Theology. Grand Rapids: Baker Books.

\section{Internet}

https://id.wikipedia.org/wiki/Politik\#Etimolog http://www.spengetahuan.com/2017/06/pengertian-politik-menurut-paraahli-terlengkap.html 